\title{
AS FORMAS DA SIMPATIA E O SEU PAPEL NA COMPREENSÃO DAS VIVÊNCIAS ALHEIAS EM SCHELER.
}

\author{
The Forms of Sympathy and Its Role in Understanding Other's Experiences in Scheler \\ Las Formas de Simpatía y su Papel en la Compresión de las Experiencias de Otros en Scheler
}

Daniel Rodrigues Ramos *

\begin{abstract}
Resumo: Objetiva-se descrever os principais traços do fenômeno da simpatia a partir da fenomenologia de Max Scheler. O problema central é demonstrar como a simpatia se mostra enquanto "lugar" privilegiado para a compreensão das vivências alheias, pois ela implica uma unificação psíquico-afetiva com quem se compadece ou se congratula. Contudo, o compadecer e o co-alegrar não podem ser entendidos, sem mais, como a apreensão de conteúdos psíquicos alheios ao modo da reprodução dos sentimentos do outro, equiparando erroneamente o simpatizar com o contágio afetivo. Assim, primeiramente, delineiam-se algumas razões e caminhos de transformações das antropologias e de consolidação histórica da ratio moderna que conduziram a tal equívoco. Em seguida, após distinguir as formais plurais da simpatia, mostrando a sua lei de fundamentação interna, discute-se em que sentido a simpatia é sofrer-com e co-alegrar ao explicitar sua estrutura intencional. Conhecer o outro, entretanto, não é só unir-se afetivamente ao próximo, mas a decisão livre, própria de um ser espiritual, de tomar parte na abertura do ser pessoal alheio, participar de seus atos intencionais. Conclui-se, então, que o simpatizar pressupõe a forma suprema do amor.
\end{abstract}

Palavras-chave: Sentimentos, simpatia, amor, conhecimento do outro.

Abstract: The objective is to describe the main features of the sympathy phenomenon from Max Scheler's phenomenology. The central problem is to show how sympathy shows itself as a privileged "place" for understanding the experiences of others, because it implies a psychic-affective unification with whom one sympathizes or welcomes. However, compassion and co-rejoicing cannot be understood as the apprehension of psychic contents unrelated to the reproduction of the feelings of the other, mistakenly equating sympathizing with affective contagion. Thus, first, some reasons and ways of transformations of anthropologies and historical consolidation of the modern ratio that led to such mistake are outlined. Then, after distinguishing the plural forms of sympathy, showing its law of internal reasoning, it is discussed in what sense sympathy is to suffer and to rejoice by spelling out its intentional structure. To know the other, however, is not only to unite affectionately with others, but the free decision, proper of a spiritual being, to take part in the opening of the personal being of others, to participate in their intentional acts. It follows, then, that sympathizing presupposes the supreme form of love.

Keywords: Feelings, sympathy, love, knowledge of each other.

Resumen: El objetivo es describir las características principales del fenómeno de simpatía a partir de la fenomenología de Max Scheler. El problema central es demostrar cómo se muestra la simpatía como un "lugar" privilegiado para la comprensión de las experiencias de otras personas, porque implica una unificación psíquico-afectiva con la que uno simpatiza o da la bienvenida. Sin embargo, la compasión y el regocijo no pueden entenderse como la aprehensión de contenidos psíquicos no relacionados con la reproducción de los sentimientos del otro, equiparando erróneamente la simpatía con el contagio afectivo. Así, primero, se describen algunas razones y formas de transformación de las antropologías y la consolidación histórica de la relación moderna que condujo a tal error. Luego, después de distinguir las formas plurales de simpatía, mostrando su ley de fundamento interno, se discute en qué sentido la simpatía es sufrir y regocijarse al deletrear su estructura intencional. Sin embargo, conocer al otro no es solo unirse afectuosamente con los demás, sino la libre decisión, propia de un ser espiritual, de participar en la apertura del ser personal de los demás, de participar en sus actos intencionales. Se deduce finalmente, entonces, que simpatizar presupone la forma suprema de amor.

Palabras clave: Sentimientos, simpatía, amor, conocimiento del otro. 
Desde que existem homens, o homem se alegrou muito pouco; apenas isso, meus irmãos, é o nosso pecado original.

Se aprendermos a nos alegrar melhor, melhor desaprendemos de causar dor nos outros e planejar dores.

(...) Assim fala todo grande amor: ele supera até o perdão e a compaixão. NIETZSCHE, Dos compassivos, em "Assim Falou Zaratustra".

Cantiga triste, pode com ela é quem não perdeu a alegria. ADÉLIA PRADO, Toada, em "Bagagem".

\section{Introdução: sobre a importância de questionar o fenômeno da simpatia}

$\mathrm{Na}$ esteira da fenomenologia da vida afetiva, por Scheler elaborada, estas linhas põem como tema a simpatia. No âmbito deste horizonte teóricofilosófico, tematizar a simpatia é colocar-se diante da questão de seu papel para a ética e para qualquer pedagogia - no sentido amplo e fundamental de condução do homem para si mesmo - que não tenha em mente unicamente o desenvolvimento das capacidades racionais do ser humano, mas também a decisiva implicação das forças do coração e dos afetos na constituição do ethos do indivíduo, de um povo ou nação, de certa época histórica. Neste sentido, é uma pergunta pela sua importância, aqui levantada dentro dos estreitos limites da cooperação da simpatia no conhecimento das experiências vivenciais do outro. Por certo, deixar ser afetado pelas alegrias e dores alheias é abrir as portas para a compreensão da vida interna do outro, sem a qual ficariam impossibilitadas a congratulação ou compadecimento entre os seres humanos, mas também aquela tristeza com a alegria do outro, a inveja, e a crueldade que se alegra com o sofrer alheio. Ademais, assiste-se atualmente à derrocada do projeto civilizacional que decide as questões éticas, epistêmicas, o destino histórico dos homens em um plano puramente racional, normalmente arbitrário contra as paixões e afetos humanos. A revalorização da conduta simpatizante, então, pode lançar certa luz, por exemplo, no estado atual dos problemas éticos.

O mundo sem a simpatia (não só sem a compaixão e a congratulação, fenômenos eticamente positivos, mas também sem aqueles negativos), se não é impossível concebê-lo ao menos na imaginação, embora em certa medida previsível desde a experiência do tempo presente, por certo, seria um mundo inóspito, árido como um deserto, pois, pobre de significados que nascem do viver humano sobre a terra; enfim, não seria o ethos de uma realidade humana, demasiadamente humana. No mundo de meras coisas ou de fatos calculáveis, onde reinaria em modo absoluto a racionalidade técnico-científica, instrumental por destinação histórica, certamente também nele seria reinante (ou já vigente em grande medida) uma profunda indigência espiritual e humana, uma vez que, como afirmara Husserl (HUA VI, p. 4)1, "meras ciências de fato fazem meros homens de fato".

Contudo, a importância de certa questão não se define pelas justificativas que realçam a sua atualidade, sobretudo, mediante a supervalorização de sua utilidade para o progresso do conhecer e para a correção do agir humano. Tal modo pragmático de conferir importância a algo é, de antemão, menosprezo aos valores intrínsecos e peculiares do que se pretende valorizar e, deste modo, cegueira ao bem que ele é: avalia-se seu valor em relação aos fins, mede-se sua monta e magnitude pelos resultados de sua finalidade, não pelas coisas mesmas. Também em relação às questões, a importância delas não se mede mediante a quantificação dos efeitos decorrentes dos conhecimentos produzidos com o seu questionamento. Pelo contrário, se elas nos são importantes, são pelo fato que elas captam o nosso interesse por si mesmas, pela capacidade de atingir nosso modo de ser entre coisas, junto aos outros, em cada época. Assim, elas nos importam pelo quão radicalmente nos afetam, "sensibilizamnos", devolvendo-nos para o cerne de nossa existência, cujos imperativos e convocações tantas vezes ocultamos e dissimulamos. $\mathrm{O}$ interesse pelas questões, em última instância, reside no poder delas nos tocar no mais íntimo de nosso ser, convocar para um modo de ser mais próprio e, assim, nos responsabilizar pelos apelos da existência. Deste modo, pensar, criar e quiçá o conhecer se manifestam como modalidades, entre outras, de responder a estes apelos. Enfim, a relevância do questionamento de uma questão é, portanto, o questionamento da importância $d a$ questão para conosco mesmos - o que na gramática se nomeia de genitivo subjetivo.

Com as questões, pois, estamos sempre enredados com o seguinte fato, mesmo sem percebêlo, mas a nós recordado por Heidegger (2006, p. 8) na conferência "O que é isto - a filosofia?": ao pensar pertence uma (pré)disposição às questões, determinada capacidade de padecer e corresponder que é traço característico do sentir em geral e dos afetos. Por outro lado, ao remeter uma afirmação de André Gide sobre a literatura para a experiência do pensar, Heidegger lembra que mesmo com beux sentiments não se faz digna filosofia ${ }^{2}$, isto é, com o recurso ao irracional não se contorna o (árido) predomínio do racional, imperioso também na história do pensamento. Não é com doses de sentimentalidades que se cura o mal e a rudeza dos racionalismos - algo que é necessário ressaltar,

\footnotetext{
1 Adota-se, aqui, a referência oficial às Obras Completas de Husserl, nas Husserliana.

2 A frase citada de A. Guide é a seguinte: " $C$ 'est avec les beux sentiments que l'on fait la mauvaise litérature”.
} 
sobretudo quando a questão do filosofar é o sentido da vida emotiva e da afetividade humana, como no caso presente, da simpatia. E, no entanto, pertence à essência do filosofar certa afetividade, se se faz justiça aos sentimentos, não os situando apenas do lado oposto da razão, no âmbito das irracionalidades e, assim, medindo-os e determinando sua capacidade cognoscitiva com os modelos e os cânones da racionalidade lógica. Deste modo, ser golpeado pelas questões, deixar-se levar afetivamente por elas, isto é, suportar a regência delas, do início ao fim da experiência do pensar, reconhecendo-lhes a importância pertencente a elas, porém, é o segredo do filosofar desde Platão e Aristóteles.

Uma vez que a filosofia se tornou negócio da razão instrumental-tecnicista, soa por demais estranha a afirmação de uma dimensão afetiva essencial ao pensar que remete de volta o filosofar para a antiga compreensão, segundo a qual sem o devido páthos não se principia no pensar. Surpreende-nos tal posicionamento, pois ela abre a possiblidade de incluir também o filosofar no nosso mundo afetivo e colocá-lo sob a regência das leis do coração humano. Esta afirmação não significa que o pensar é algo de irracional, sentimentalidade de alguns filósofos desvairados. Com ela, apenas se recorda que ao pensar é necessária certa fineza do espírito, que a ciência negligenciou. Dizendo com Pascal (2005, p. 236), para ter visão clara e apreender os princípios, dos quais a filosofia desde os inícios se fez "ciência", é preciso tê-los como "coisas tão delicadas e numerosas", de tal modo que "é necessário ter um senso bem delicado e bem claro para as sentir e julgar de modo justo e correto, segundo este sentimento, sem poder, no mais das vezes, demonstrá-lo por ordem como em geometria"3. Apartada das forças e da justeza necessária para penetrar a ordem do coração, próprias ao esprit de finesse, a razão geométrica da ciência avança amplamente, porém, é fraca em finura e tende se afirmar como um poder brutal de domínio. Contudo, também é certo que um coração impaciente para suportar a especulação, desabituado ao esforço e ao rigor do raciocínio, tende naturalmente à estreiteza do espírito. Mais do que técnica e procedimentos metodológicos para (aprender a) pensar, necessária é a paciência para com o fruto que lentamente amadurece e se colhe no silêncio, a ausculta das vozes do ser que talvez, em breve tempo, só poucos poetas e alguns crentes poderão sentir e pensar. Deste modo, o "reto" filosofar, sem abandonar a finura do espírito que penetra profundamente nos princípios e os capta imediatamente, em só um lance do olhar, não se demite do esforço da contemplação e da demora do raciocínio, excluindo a precisão das de-monstrações, o rigor no exercício do lógos, claro, postos em ação segundo a sua essência e seu método.

Se entendermos o filosofar como possibilidade de existir, então, o que vale para o pensar, vale de igual modo ou em maior medida para o homem e para sua tarefa histórico-fática de ter sempre que produzir a si mesmo e, em íntima conexão a isto, realizar as obras espirituais que a ele cabe criar em cada época. Para tanto, ter-se-ia que mostrar, por exemplo, pertencer à arte um sentir intuitivo, mas também que ela possui, certamente, seu modo peculiar de pensar (talvez, com as mãos) $)^{4}$, de raciocinar e demonstrar, cuja aprendizagem é tão longa, exigente, rigorosa quanto a do raciocínio lógico-matemático. Para tomar, por exemplo, apenas uma das experiências artísticas, a pintura faz evidente que o pintor é aquele quem possui o dom do visível, mas é "claro que esse dom se conquista pelo exercício, e não é em alguns meses, não é tampouco na solidão que um pintor entra em posse da sua visão" (Merleau-Ponty, 2004, p. 19).

Considerações neste sentido, porém, conduzem muito além do presente propósito de indicar a participação dos afetos no conhecimento de certos dados objetivos. Especificamente, propõese tematizar o fenômeno da simpatia e a sua participação na compreensão das vivências alheias. Fenomenologicamente, alcança-se este propósito se, antes, rompe-se com o preconceito dominante, segundo o qual o simpatizar seria um mero sentir o mesmo que o outro sente, em igual intensidade, preservando a qualidade do sentimento alheio (sofrer, por exemplo, a dor exatamente igual à do outro em modo idêntico). Porém, tal pré-compreensão faz da simpatia senão um mecanismo reprodutivo e imitativo das emoções e sentimentos alheios, para não dizer que a transforma em um sentir reativo, mecânico. A necessária desconstrução prévia desta interpretação passa, então, pela discussão dos motivos e caminhos pelos quais a riqueza e profundidade da estratificação da vida afetiva é aplainada na superfície da mera sensação com suas leis bio-fisiológicas, como se fosse o único estrato. Trata-se de uma objetivação do sentir humano às custas do desconhecimento e negação do caráter intencional e compreensivo da vida afetiva. Nisto, mesmo que indiretamente, realça-se o porquê tão facilmente se exalta a simpatia como uma valorosa atitude ética ou condena-se a sua falta em tempos presentes, porém, sem atentar, que cotidianamente se a converte em mera reação de condoer-se ou compadecer, subjuga-a a certo deixar-se contagiar pelo sofrer alheio, aliás, negando as formas plurais dos atos simpatizantes.

4 Como sugere M. Dufrenne, (1972, p. 58): "Como o sentido, na obra de arte, está totalmente imanente ao sensível, assim a invenção do sentido, no artista, é totalmente imanente à tecnicidade. Visto que jamais há possiblidade de desqualificar a tecnicidade: o fazer não é somente a prova do pensar, é já certa maneira de pensar e de viver conforme o pensamento. O trabalho do artista como o do sábio moderno num outro plano, reconcilia ação e contemplação. Feliz quem pensa com as mãos”. 


\section{(Des)caminhos e motivos de consolidação da racionalidade desprovida das forças do coração.}

O ethos moderno é extremamente favorável, como tem mostrado a história atual, para o crescimento incontível do sistema dos fins com suas metas de organização e controle total. Impulsionado pela racionalidade técnico-científica, caracteriza-se por ser um sistema a serviço de um poder maquinal e global, contra a qual, já no fim do século XIX, Nietzsche foi um dos primeiros a levantar a sua voz e crítica $^{5}$. Se neste poder no qual se transformou a ratio vibra algum ímpeto vital, mesmo que seja a tendência do viver humano se voltar contra ele mesmo e se menosprezar, seu dinamismo é o da busca incansável de sua conservação e elevação. A essência de todo o poder é, pois, o querer ultrapassarse, da superpotencialização. Deste modo, é justo ampliar a pergunta que Heidegger, na supracitada conferência, faz para a essência da filosofia para o amplo horizonte da essência do viver humano com suas multifacetadas formas de se concretizar: Onde e por quem é decidido que ser a ratio a senhora do homem, do seu agir, pensar e do conhecer? Não se arvorou o homem desta disposição e, nos tempos atuais, ela não o dominou, como que por vingança, invertendo a ordem do poder e do querer? É nestes embaraços que nos (co)implicamos quando nos colocamos às voltas da importância de questionar o fenômeno da simpatia ao dar conta do desprezo com que este questionamento foi desqualificado e postergado.

Ora, é verdade que as antigas antropologias conceberam o homem a partir do que nele há de supranatural e espiritual; portanto, daquilo que se mostra como o mais nobre, apresenta-se como o mais divino ou demoníaco, na ambiguidade deste último conceito. E mesmo com este olhar para as alturas do espiritual de si mesmo, apesar das vertigens, "o homem”, como alerta Scheler (2003, p. 95; 2007b, p. 175), "tinha uma consciência acentuadamente mais profunda de sua animalidade nos tempos em que se julgava um deus do que em tempos em que, rindo maliciosamente, se denominava animal”. A época desta malícia escarnecedora do espiritual é o tempo das modernas antropologias. Ao contrário das primeiras, elas fizeram um movimento descendente, subjugando todas as dimensões humanas para a sua constituinte e não desprezível animalidade. É nesta descendência, que queria valorizar a corporalidade e a carnalidade humanas, mas ao contrário do pretendido, o homem com todas as suas dimensões, também o viver no espírito, foi rebaixado para âmbito do orgânico, do biofisiológico, do cerebral. Certamente, isto se deu em razão de uma ingênua

\footnotetext{
5 A afirmação se apoia na interpretação de G. Vattimo (2017, em especial pp. 330-346), para quem a filosofia da maturidade de $\mathrm{Ni}$ etzsche está intimamente ligada com a libertação da viver humano das estruturas do mundo da ratio em geral, prefigurada naquele homem vindouro, chamado pelo filósofo de Übermensch.
}

compreensão do sentido humano de ser corpo, carne, de ser zwós, já que passou a ser igual interdito pensa-lo como bíos, isto é, como um espírito encarnado, temporal e historicamente existente. Inevitavelmente, a vida humana se reduziu aos mecanismos bio-neuro-fisiológicos. Assistimos ainda a este movimento de descendência, por não dizer, de animalização conforme as leis específicas daqueles mecanismos e, consequente, de decadência na compressão do sentido da condição do homem ser uma existência encarnada, de ser não puro espírito, mas sim incorporado.

Nesta via de mão única para baixo, também os sentimentos descem para um patamar inferior, reduzidos às sensações e aos estados sensitivos do corpo físico e, por isto, se tornaram algo de irracional, dominados pelos mecanismos “automáticos” e não intencionais de reação orgânica. Os sentimentos ficaram encarcerados na pele do corpo físico. Porém, outros sentimentos coexistem com os sentimentos sensíveis, constituem dimensões mais nobres do homem, sendo eles os responsáveis pela consciência de si, de sua corporalidade e de sua situação no mundo (Scheler, 2000a; 2000b). No segundo estrato da profundidade da vida afetiva, encontram-se presentes os sentimentos vitais, irredutíveis às sensações e aos estados localizados e causados pela irritação e excitação de fatores externos, porque pertencem à inteireza e unidade da consciência do corpo vivido ou corpo-próprio (Leib). Esta consciência de um corpo no seu todo, evidentemente, é aquela de um eu-do-corpo-próprio ${ }^{6}$, íntima e diretamente vinculado à consciência corporal, percebendo a si mesmo como encarnado numa situação vivida por meio, por exemplo, ao sentir-se vitalmente bem ou ao sentir-se desvigorado. Nesta ligação íntima ao corpo, o eu, porém, também sabe de si como um indivíduo particular e concreto, é consciente que a ele pertence uma interioridade que se manifesta em certo fluxo de vivências que são só suas e de nenhum outrem. Na ausência desta consciência, ele não penetraria na própria natureza corporal e não poderia colhê-la como "meu corpo". Da genuína corporalidade, portanto, não se sabe mediante tomada de conhecimento de reações orgânicas, mas por meio dos sentimentos psíquicos ou anímicos, que constituem o terceiro grau da estratificação da vida afetiva. Estes, com efeito, já se apresentam de certo modo independentes da datidade do corpo vivido: sente-se triste e sofre-se profunda dor psíquica, mesmo quando se está sentindo o bemestar corporal. Por meio dos sentimentos anímicos, então, homem se situa noutro estrato da vida afetiva, aquele das qualidades do eu. No nível mais profundo, encontram-se os sentimentos espirituais, aqueles referidos ao núcleo da pessoa e, em razão desta referência a este centro livre ou indiferente às leis psicofísicas, escapam ao mais rígido controle

6 Cfr. M. Scheler, Der Formalismus in der Ethik, p. 336, 340; tr.it., p. $412,418$. 
e supervisão do eu e jamais se concretizam como estados de ânimo. São os sentimentos que captam o sentido da existência pessoal, denunciam a sua ausência quando ele se obscurece. Se livres de qualquer motivação psíquica, de toda tentativa do eu criar, inventar ou manter o sentido do próprio viver, nascem, crescem e se consumam do centro da pessoa, da profundeza abismal de cada ser humano. Porém, "extravasam" no seu mundo circundante com seus objetos, colorindo-o com certa tonalidade afetiva. Enfim, graças aos sentimentos espirituais, o ser humano sabe-se corpo, carne, mas também se sabe como único e irrepetível, chamado a concretizarse historicamente enquanto a tarefa singular de ser pessoalmente no mundo.

Considerando esta rica estratificação da vida sentimental do homem, percebe-se que o seu corpo animado foi subjugado às leis do conhecimento intelectivo-científico. As leis de sua corporalidade, a partir da época moderna, tornaramse, exclusivamente, leis naturais. Também aquelas de sua alma (psique) com suas vivências internas, quando a vida psíquica e os sentimentos anímicos foram sujeitados às leis impostas pela psicologia empírica. As leis da compreensão (de si e do outro), regidas pelo ser-espiritual e pessoal do homem, não habitam mais seu corpo vivido e sua alma. De igual modo, o espírito e seu modo peculiar de saber e sentir a si, em nome do rigor científico, também só poderiam ser explicados e, para tanto, eram necessárias que as mesmas leis da natureza fossem aplicadas a esta dimensão do profundo. Saber de si e dos outros, conhecer as vivências anímicas alheias, é, no movimento de descendência acima acenado, apenas possível sob as leis que importam a uma perspectiva teorética do conhecimento da vida, não do saber compreensivo do viver. Porém, a experiência de viver não é explicar-se, mas compreender-se: "Conforme o seu ser-assim (Sosein, essência) e seus atos-correlatos noéticos, porém, a pessoa e sua noesis (é espírito) somente compreensível” (Scheler, 2009, p. 219). Saber de si e dos outros é unicamente realizável por meio da compreensão e de suas leis próprias, conhecimento que nem a consciência intrapsíquica é capaz de consumar perfeitamente, sobretudo quando sua essência e dinamismo são teoreticamente predeterminados. Pois, deste modo, substitui-se inevitavelmente a causalidade psíquicaindividual, indissociável de cada eu, concretamente determinado e com suas singulares motivações (advindas pela compreensão de sentidos), pela causalidade natural, isto é, por uma correspondência mecânica entre causa e efeito segundo modelos e tipos genéricos (Scheler, 2000a, pp. 520-521).

Por conseguinte, tanto no plano físico quanto anímico, aquela via histórico-descendente que o homem percorreu na busca de autodeterminar se faz, ao apelar às leis naturais, pela adoção de uma impostação teórico-objetivante na interpretação de como ele é si mesmo, isto é, na determinação de sua essência. Uma constatação óbvia, porém, importante, pois lança uma luz no fato da simpatia ser nos dias de hoje um fenômeno cada vez mais raro. Pois, se a estrutura emotiva do homem, sob poder das leis do conhecimento técnico-científico, é desviada para a monotonia dos sentimentos sensórios e para o plano único dos estados sensitivos, fica boqueada qualquer comunhão do sentir. Somente nas dimensões, nas quais os sentimentos se fazem genuíno ato intencional, dirigido ao outro em um movimento de compreensibilidade, portanto, não se mostrando apenas como puros mecanismos de reação, é possível a um ser humano sentir-se com o outro, sentir o alegrar-se e o sofrer alheios em unidade com ele, como também ressentir alegremente por sua dor ou tristemente por sua alegria. Simpatizamo-nos em razão de ser-nos dado, de antemão, a possibilidade de compreender intencionalmente as vivências psíquicas alheias. Pelo contrário, os sentimentos sensoriais, por serem sempre estados atuais e organicamente localizados, caracterizam-se por um sentir desprovido de originária temporalidade, pois não podem ser pressentido (vorfühlen) no presságio de uma espera, ressentido na memória, novamente sentido ao prolonga-lo ou retê-lo de outra maneira (wiederfühlen) ou sucessivamente sentido por outrem mediante um ato intencional compreensivo (nachfühlen), enfim, consentido (no sentido de participado por meio de um acordo do coração, mitfühlen) (SCHELER, 2000a, p. 336). Tudo isto é impossível, por exemplo, para o estado doloroso de uma odontalgia. Localizada na periferia do corpo físico do outro, presa a seus mecanismos fisiológicos, hermeticamente fechada à compreensão, ela pode ser unicamente a dor solitária do outro.

Em Vom Sinn des Leides, Scheler (2008a) aponta os motivos desta objetivação da condição humana por meio do conhecimento científico, que também atinge a natureza na crescente luta da civilização contra os seus perigos. Considerando o desenvolvimento histórico das formas associativas entre os humanos, do ponto de vista ontológicovivencial, esta objetivação tem suas raízes na busca do homem de aplacar o sofrimento, no empenho para controlar as tragédias naturais, no contorno da fragilidade do corpo humano, no embate contra as vicissitudes dos vínculos humanos e contra as falhas das normas reguladoras das instituições sociais, sempre maiores com o fortalecimento e engrandecimento das complexas estruturas do Estado e da sociedade. Na organização e divisão econômica do trabalho, acompanhada pela hiperespecialização do saber e pelo aumento das riquezas, no intenso dispêndio de energia dispensada ao trabalho, no refinamento da cultura, dos costumes e das sensações, enfim, em vários aspectos espirituais específicos dos povos ocidentais, é notório o anseio de asseguração e aumento da felicidade, melhor, da 
intensificação do prazer, principalmente, pela busca de recursos que aplacassem a dor e diminuíssem as sensações dolorosas. Ao longo do processo civilizatório, vê-se uma busca de viver sem dor e sofrimento que caracteriza, em termos axiológicos, a história espiritual da humanidade ocidental como um processo motivado por uma valoração eudemonista da civilização e cultura - em certo sentido hedonista, conquanto que vincula o aumento de felicidade com a eliminação do sofrimento e intensificação do prazer e do bem estar -, a qual na época moderna possui traços bastante específicos (em geral, ligados aos valores econômicos do trabalho e ao lucro). Para a realização deste sonho da felicidade plena da humanidade, é inegável que a emergência das ciências e seu esplendoroso desenvolvimento exerceram papel significativo, por exemplo, promovendo o avanço dos meios, instrumentos e mecanismos técnicos por ela criados para o domínio racional da natureza. Na crescente luta técnica da civilização contra a natureza, porém, o poder dado ao homem pelas ciências não levou seguramente à felicidade, como diagnosticou Freud (2011, p. 31) já no início do século XX ao descrever a "profunda, duradoura insatisfação com o estado civilizacional" do homem moderno. Assim, pelo contrário, assiste-se ao crescimento quantitativo das dores e do sofrimento, bem como é cada vez maior a variedade qualitativa de modos de sofrer. A capacidade de suportar as mesmas sensações do homem primitivo e os sofrimentos elementares do viver humano, por exemplo, o medo da morte, é cada vez menor; uma incapacidade que se agrava como o aumento do progresso civilizatório. A alegria dos povos primitivos, observa Scheler (2008a, p. 49), era mais contínua e raramente perturbada, não obstante fosse mais exposto aos perigos naturais e susceptíveis às revoltas da natureza. Conclui-se, então, que a via histórica de inestimável progresso civilizatório - a mesma ao longo da qual as antropologias passaram de uma a outra e testemunham como se transforma o modo do homem a conceber a si, seu mundo e seu destino cada vez mais determinado pela razão e pelo conhecimento técnico-científico -, na verdade, representa um enorme regresso.

Do ponto de vista dos modos que a humanidade ocidental-europeia encontrou para conceber pratica e teoricamente a vida instintiva e afetiva, para vivela e consumar o seu sentido, o desenvolvimento civilizatório pode ser caracterizado por uma perda de sua capacidade simpatética em favor da crescente "hipertrofia do intelecto" (Hypertrofie des «Verstandes») (Scheler, 2009, p. 42). Em termos simbólico-espirituais, esta situação se faz evidente. $\mathrm{O}$ modelo do homem civilizado, em tempos que se caracterizam pelo progresso extraordinário e da aplicação técnica no domínio da natureza à procura do controle do sofrimento, sem sombras de dúvidas, é figurado na imagem do homem adulto, de gênero masculino (Scheler, 2009, p. 42-43), isto é, da humanidade determinada pela clareza da racionalidade lógico-matemática que nela teria suas mais excelentes forças e poderio. O homem moderno, de modo paradigmático, deixa-se expressar na figura do "homo sapiens" que, como membro de uma civilização intelectual hiperviril, submete todos os valores e bens nobres (naturais, vitais, espirituais e religiosos) ao único grupo de bens e valor: os da utilidade (Scheler, 2009, pp. 114-115). Na gradativa consolidação histórica desta imagem, culminando com o tipo burguês do "homo capitalisticus", afirma-se a compreensão de humanidade a partir do adulto que atrofiou a imaginação vívida da idade infantil, perdeu suas imagens eidéticas primordiais e arquetípicas, fenômeno acompanhado da regressão da percepção do sentido do transcendente, que os povos primitivos preocupavam encontrar em toda parte e proteger de modo originário. Nesta sintomatologia, Scheler lê na evolução das forças cognoscitivas que se aprofunda na diminuição da capacidade do homem civilizado em unificar-se afetivamente com os demais seres humanos e, numa cooperação universal, com o vivente em geral e com toda a natureza numa perspectiva cósmica, como é atestável nas primitivas culturas ${ }^{7}$. Nelas, ao contrário, esta ampla capacidade simpatética está associada, por sua vez, com o saber que é simbolicamente atribuído como específico do mundo infantil e associada às forças intuitivas próprias do feminino ${ }^{8}$. E isto não se deve, de modo
$7 \quad$ Descrito, por exemplo, por Jung (1977, pp. 36-37) como um outra pessoa, animal, vegetal ou algum objeto: "Entre estes povos, para quem a consciência tem um nível de desenvolvimento diverso do nosso, a 'alma' (ou psique) não é compreendida como uma unidade. Muito deles supõem que o homem tenha uma 'alma do mato' (busch soul) além da sua própria, alma que se encarna numa animal selvagem ou numa árvore com os quais o indivíduo possui alguma identidade psíquica”. Por isto, as tribos acreditam ter várias almas e, entre os povos originários, o acidente mental mais comum é a fragmentação ou dissociação da alma em muitas, certa "perda da alma". Por outro lado, "esta crença traduz o sentimento de alguns povos de que cada um deles é constituído de várias unidades interligadas apesar de distintas”. Por sua vez, Scheler (2009, p. 30) reconhece nestes fenômenos autênticas identificações primitivas, colocando a seu lado o culto aos antepassados presente nos povos primitivos como expressão da identificação e vinculação emocional dos descendentes com seus predecessores. Para ele, os atuais fenômenos das massas, tal como aconteceu entre os cidadãos alemães e o Führer, prolongam esta dimensão dos tempos históricos primevos.

8 A língua grega doa um exemplo desta vinculação. Unir-se em coração a outro, tomar parte no afeto dele é nomeado pelo verbo sym-

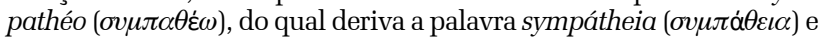
dá origem à palavra portuguesa simpatia. Contudo, ser tocado nas profundezas do próprio ser, em grego, se diz com o verbo splagnchnízo, $\sigma \pi \lambda \alpha \gamma v \chi v i \xi \omega$. Por nomear esta disposição tipicamente humana, em sentido ativo e passivo, significa provar a compaixão, dispor-se e sofrê-la a fundo. Tal querer e deixar-se sucumbir à compaixão se entrevê por meio do substantivo correlato ao verbo que nomeia o ato: splágchnon, $\sigma \pi \lambda \alpha_{\alpha \gamma \chi \eta v o v}$. Porém, antes de conotar o ato da compaixão, o referido substantivo denota vísceras, ventre, assim como regaço e útero materno. Somente metaforicamente, o substantivo possui o significado de ânimo e coração enquanto o lugar dos afetos, assim como o que se contém nesta esfera, em especial, o afeto da ternura e da compaixão. Seguindo estes indícios linguísticos, percebe-se que a compaixão tem a ver não com um acontecimento emotivo que atinge a superficialidade das sensações orgânicas ou com qualquer passageira comoção psíquica, mas sim que acomete o ser humano nas estranhas de seu ser, tomando-o com uma tonalidade afetiva-receptiva capaz de despertar 
algum, em razão da humanidade arcaica valorizálas, sem lucidez, como formas subdesenvolvidas de conhecimento, mas sim, por saber, com clareza intuitiva, o positivo valor destas forças. Portanto, em razão do primitivo saber que elas são as únicas capazes de entrar em comunhão com as profundezas escuras e inefáveis mediante uma unificação afetiva com todo o real, não só aquele que vive e respira, e, assim, capazes de direcionar o ser humano a um conhecimento compreensivo e erótico, no sentido originário do termo. Não por acaso, é a mulher que, desde as culturas mais arcaicas, é a guardiã dos valores e bens mais nobres, o da vida por meio do cuidado maternal (o "direito natural" sobre os filhos) e os valores espirituais e religiosos, contra à subordinação aos imperativos utilitários e econômicos das necessidades cotidianas de subsistência. Ao contrário, na civilização do progresso e do utilitarismo, fruto da tão aclamada evolução, somente são encontrados restos desta capacidade de se unir afetivamente ao universo vivente. $\mathrm{O}$ último dos homens que soube reaviva-la teria sido Francisco de Assis (Scheler, 2009, pp. 94, 97-98), em cuja espiritualidade a relação arquetípica com o feminino, na figura da mãe terra, vigora em harmonia com a luz do irmão sol, figura paterna e masculina do bom Senhor e de seu eros criador $^{9}$, que aflui para uma simpatia vital-cósmica com toda natureza infrahumana.

Contudo, a sobrelevação das forças cognoscitivas do homem civilizado é também, paradoxalmente, a decadência delas, não somente porque quase se extinguiu a capacidade de penetrar na profundeza de tudo com a aguda mirada do coração. Antes, por uma lei de fundamentação das dimensões do humano, segundo a qual elas não poderem se elevar sobre si mesmas se as inferiores permanecerem subdesenvolvidas. Se o homem é o único ser vivo que, por força do espírito é o "asceta da vida", aquele capaz de recusar a mera efetividade como última ideia e origem das coisas, portanto, cujo modo de ser significa "lançar um vigoroso 'não' de encontro a este tipo de realidade" (Scheler, 2008c, pp. 42, 44; 2003, pp. 50, 52) para ascender às mais altas e mais nobres, é incontornável a seguinte necessidade:

Antes de tudo, carece-se desenvolver todas as forças do ânimo (Kräfte des Gemütes), não somente esta ou aquela de diferente espécie, quando um ideal de possível humanidade plena deve ser alcançado no homem. (...) A força mais valorosa do ânimo e, igualmente, por sua essência a menos condizente aos homens em geral, não pode ser formada plenamente, quando a menos valorosa, porém, mais geral, não está completamente formada. Desaparecida

as profundas forças criativas de seu ânimo e, assim, fazê-lo fecundo e generativo, independentemente de seu gênero.

9 Referência ao cântico ou poema místico composto pelo santo, conhecido por "Cântico do irmão sol”, incluído nas "Fontes Franciscanas” organizada por M. Teixeira, 2004, pp. 104-105. para um indivíduo ou para toda a cultura de uma época a unificação afetiva cosmovital, a qual os índios e os gregos teriam desenvolvido em grande parcialidade, ou julga-se que ela não seria nenhuma "genuína e verdadeira" fonte metafísica de conhecimento para certas faces atingíveis do universo subsistente em si, se a toma por superada em seu sentido cognitivo e valor por meio da ciência, do Cristianismo ou da humanidade, então, corta-se também as originárias raízes e as fontes de alimentação para as todas "mais altas" da vida emocional e simpatética (Scheler, 2009, p. 112, tradução minha)

A unificação afetiva (Einsfühlen) é apenas uma das formas da simpatia, porém, a mais arcaica. Por esta razão, porém, é capaz de alcançar ampla envergadura, atingindo o cosmos por inteiro. Seu caráter primitivo e pré-teorético é sua força vital. Não obstante renegada na história da humanidade ocidental, ela é a fonte de um saber primigênio, uma espécie de conhecimento que se cumpre sem que se formem juízos sobre as vivências do outro, sobre a natureza ou qualquer ser aninado, assim como a respeito das qualidades destas vivências. Não é, pois, um ato puro do intelecto, muito menos o saber de um expectador que, numa postura teorética-cognoscitiva, julga saber o que outro sente e, reproduzindo o sentimento, crê viver o mesmo que o outro vive: alegra-se com ele ou compadece-se, tomando a dor e alegria dele como sendo sua. Mas isto pode não ser mais que um contágio emocional, como acontece costumeiramente com os animais em rebanho; também quando os homens se encontram em massa e se comportam despersonalizadamente. Na verdade, em razão desta impostação intelectualista, que se toma o simpatizar unicamente por um projetar-se na interioridade da vida emotiva do outro, sem se dirigir intencionalmente para a situação ou fonte de dor e alegria do outro, e ingenuamente se reproduz de modo mecânico o sentimento de outrem. Simpatizar não é mero saber ou juízo relativo à vivência alheira, é um verdadeiro sentir o sentimento de outrem, o que, porém, não implica sentir o mesmo que o outro, participar subjetivamente das vivências alheias mediante sentimentalidades eufóricas ou condoídas. E não é só pelo compadecimento e pela congratulação que se simpatiza com as vivências alheias, bem o mostra a indiferença - no sentido de "automático", isto é, privado da intencionalidade compreensiva da motivação noético-espiritual, livre por natureza (Scheler, 2009, pp. 56-57) - de sua forma mais primitiva frente à emotividade que se confere atualmente a tais modos de simpatizar. Entre a genuína identificação psico-afetiva da unificação afetiva até a compreensão do sentimento alheio em um ato intencional a ele dirigido, passando pelo intencional sentir-com o outro (dirigido ao mesmo 
complexo de valor), há uma concreção muito variada de fenômenos, modos e funções simpatizantes, como também se abrem, na passagem de um polo ao outro, vários desvios manifestos nas formas do contágio afetivo, da introjeção psíquica. Desconsiderar, então, as formas multifacetadas da simpatia é encaminharse para as distorções teoréticas do fenômeno, privilegiando um conhecimento das vivências afetivas e anímicas infundadas na própria base fenomênica.

O saber em torno da vida afetiva do humano é como uma escada que eleva para as espécies mais altas do conhecimento e conduz para as formas próprias do espírito, para o amor. Porém, negar os primeiros degraus é pisar em falso e decair já nos primeiros passos. É ainda, por certo, dar um passo falso rumo para uma patologia, não obstante exaltado como ato moral, quando se preza utilitária ou exacerbadamente a virtude da compaixão. Sinal e consequência de nossa inexperiência com a alegria que surge generosa e gratuitamente do centro profundo de nossas almas. Conhecemos até agora muito pouco da alegria, porque ela nos trai tanto mais fazemos dela meta e destino de nossas buscas calculadas, de nosso fazer produtivo, de nossos projetos de asseguração da felicidade (Scheler, 2000b, pp. 64-65 ; 2000c, pp. 75-76), enfim, ao fazêla mérito de nosso agir e distinção do sujeito ético. Ao contrário, vivemos desta algofilia espiritual, a saber, do gozo em tornar sublime e grandioso o valor do sofrimento pela dor do próximo, de certa avidez por compaixão, que faz esquecer a alegria e ata a simpatia ao preconceito dominante que a reduz ao mero sentir o mesmo que o outro, tal qual ele sente. Na perspectiva de uma crítica à valoração ressentida que resulta em uma inversão axiológica, no caso, a superestima do compadecimento do padecimento alheio, acompanhada da subestimação da congratulação com a alegria do outro, muito certeiramente, prega o Zaratustra de Nietzsche: este desconhecimento da alegria é o nosso pecado original, não a carência de compaixão como o sinônimo único da simpatia. "Deste modo, estais prevenidos contra a compaixão; dali ainda virá uma pesada nuvem para o homem" (Nietzsche, 2011, p. $86)^{10}$.

10 Deve-se recordar com Scheler (2009, pp. 28-29) que, por outro lado, o julgamento de Nietzsche a respeito da compaixão, apesar de sua penetrante crítica à compreensão positivista e teorias evolucionistas do fenômeno, ainda não está depurada da tendência de interpretá-la a partir do contágio afetivo. Consequentemente, Nietzsche teria feito uma errônea valoração da compaixão ao determina-la, essencialmente, como um instinto, aliás, depressivo e contagioso. Na direção desta crítica à compreensão vitalistamecânica da simpatia (Mitfühlhen), que este argumento é retomado em Das Ressentiment im Aufbau der Moralen. Nesta obra, ao demonstrar o caráter ressentido da concepção moderna de amor como humanitarismo, Scheler (2007a, p. 98) acentua que o genuíno amor à pessoa humana é reduzido à um ardente e entusiasta sentir o sofrimento alheio. Porém, este ato não poderia ser confundido pelo verdadeiro simpatizar, mas entendido como manifestação do ressentimento moderno e burguês. Deste modo, trata-se de uma suposta interiorização reprodutiva de estados emotivos alheios, que tem por base a superestimação da dimensão psicofísica do

\section{As múltiplas faces da simpatia e o seu papel no conhecimento das vivências alheias.}

Simpatizar é sentir as (mesmas) dores e alegrias do outro? Por motivo do restrito campo visão a partir do qual pergunta é, costumeiramente, formulada, a resposta a ela deve ser, em primeiro instante, negativa. É que ela opera, na estreiteza da vista, uma negativa redução da essência e formas da simpatia, que provém de vários fatores já acenados. Em primeiro lugar, pelo fato que se desconsidera por completo as leis de fundamentação interna dos fenômenos da simpatia ${ }^{11}$, homem com suas leis na elucidação e compreensão de fenômenos tipicamente espirituais. Por conseguinte, os juízos de valores daí resultantes seriam farsas valorativas, pois se fundamentam na inversão ou reviravolta dos valores, nascida do ressentimento, que subjuga a "ordem do coração" às leis periféricas das afecções sensitivas. Portanto, conforme Scheler (2000a, p. 283; 2007a, p. 65), o próprio Nietzsche, embora tenha criticado esta ressentida inversão e falsificação dos valores, estaria de certo modo preso à tendência de determinar a ética e os atos morais a partir de princípios vitalistas, chegando à conclusão que a simpatia e os sentimentos inerentes seriam tão somente manifestações da decadência da vida (meros contágios, disse-se acima; certa contaminação afetiva propagada pela "consciência" instintiva própria a rebanhos ou bando de animais). Assim, a compaixão e a simpatia como tal seriam instintos contrários àqueles outros que conservam e potencializam a vida. Grosso modo, esta tendência, dominante a partir do século XVII, orienta-se a restringir todo o dinamismo da vida afetiva à estados emotivos e explicá-la exclusivamente a partir de princípios mecanicistas, inclusive aplicando-os à conservação e potenciação da vida. Nisto, decorre-se não só em uma concepção errônea do sentido da vida humana e de suas manifestações (crescimento, conservação, desenvolvimento evolutivo e outros), bem como em princípios éticos que não permitem o referimento da essência da vida a valores mais altos, a saber, os espirituais e o sacros. Com isto, todos estes valores e os atos espirituais, próprios ao estrato mais nobre da vida humana, são remetidos para o âmbito dos sentimentos vitais, aos impulsos e tendências sensitivas inerentes a qualquer vivente, à mera animalidade. Deve-se acrescentar que, de igual modo, todos os demais sentimentos espirituais, como a felicidade, o desespero, o tormento ou paz de "consciência", não devem ser compreendidos a partir das leis piscofísicas do viver humano, decorrendo no mesmo erro acima em considerar os valores vitais como supremos. Daí que na definição da genuína simpatia é importante não só ter em boa ordem a tábua de valores, retendo por mais nobre o valor da congratulação com a alegria alheia, mas também ter fixo que onde se dê a simpatia o que é decisivo não é a alegria nem a dor, mas sim a referência ao que é nobilíssimo: no simpatizar dirige-se para a dor ou alegria porque são manifestações do sofrer e do regozijar de uma pessoa espiritual e, como tal, um ente singularíssimo e insubstituível. Por esta razão, a simpatia pressupõe o amor à pessoa individual (cfr. nota 13). Em todo caso, Nietzsche teve o mérito de identificar uma forma dissimulada de simpatia ao denunciá-la como uma reação dolorosa dos homens débeis à dor alheia, embora tenha erroneamente chamado esta reação típica à (ardente) afetação sensitiva com o nome de simpatia. Nesta postura e entendimento tão cotidianos se dirige, na verdade, à própria reação de dor, converte-se a simpatia em mero gozo com a própria capacidade de condoer-se (Scheler, 2009, p. 53).

11 As relações internas e do desenvolvimento genético dos fenômenos da simpatia expressas por esta lei de fundamentação essencial são descritos em "Wesen und Formen der Sympathie" (Scheler, 2009, pp. 105-111). Em síntese, são elas: I) A Einsfühlung (unificação afetiva) é o fundamento da Nachfühlung, o sentir que "repete" a vivência alheia, seu ato afetivo, isto é, ato que refaz em quem sente o sentimento alheio, constituindo no primeiro um fato psíquico fenomenologicamente distinto; II) Esta forma de sentir simpatizante é, por sua vez, o fundamento do Mitgefühl, o sentir-com, porém, enquanto ato compreensivo que se dirige intencionalmente à vivência alheia - simpatia em sentido estrito, o simpatizar propriamente dito; III) Este último ato funda o amor ao homem (humanitas); IV) $\mathrm{O}$ amor ao homem funda o amor à pessoa e a Deus. Acima, descreve-se a interrelação destes atos, porém, vagamente, apenas em medida necessária para esclarecer o argumento no atual momento 
a seguir, suscintamente descritas. No seu conjunto, estas leis traduzem que as forças sublimes do ânimo ou do coração necessitam, para se desenvolverem, do pleno desdobramento das potencialidades mais primitivas, o que implica a cooperação de diferentes atos afetivos e de conhecimento dos valores. Com efeito, para se chegar à forma espiritual mais elevada das forças do coração, a saber, o amor acósmico à pessoa $^{12}$ (com seus atos noéticos, compreendendo o sentido destes), precisa-se de um amor que se mostre ainda como amplo e universal pela humanidade como tal. Porém, não se trata de amar um abstrato ser de razão, mas antes a humanitas como a esfera concreta na qual se doa a alteridade do outro que, na sua diferença, faz-se tão "real" quanto aquele que o ama. Necessita-se de um amor espontâneo ao outro, simplesmente porque ele se mostra como um outro ser humano (SCHELER, 2009, p. 107) e, como tal, detentor de valor(es) único(s). Pois, o simpatizar está intimamente ligado com o "ter-por-real" o sujeito com qual sente-se-com; caso contrário, ter-se-ia uma situação de autoerotismo, egocentrismo, solipsismo ou outra de semelhante gênero, na qual se tem o outro somente mediante uma representação, como (auto)imagem, ilusão ou ficção. Sem este modo de se ater ao álter e deter-se junto a ele como uma "realidade" única, concretamente existente como ser-

da discussão, a indispensável cooperação entre eles. Por certo, necessita-se muito mais para uma límpida descrição fenomenológica da interdependência dos fenômenos.

12 Enquanto a forma nobilíssima do amor, este possui o sentido de um vínculo universal, a consciência de uma solidariedade baseada no enlace e na unidade ôntico-metafísica de todos os seres individuais. Trata-se do amor que ultrapassa as concretas relações interpessoais, de pessoa humana a pessoa humana ou de pessoa humana a pessoa divina, pelas quais aprofunda-se sempre mais no conhecimento do outro como sendo indivíduo único em seu gênero, isto é, singularíssimo e insubstituível, ao mesmo tempo, que rompe-se com as intermediações das compreensões prévias, por exemplo, as relações sociais com as suas prévias determinações de papéis. Neste sentido de ultrapassagem, o amor acósmico não deve ser entendido como contrário ao amor à pessoa, mas como o seu destino, no sentido de ampliar o conhecimento no amor do outro para a vastidão da existência pessoal como um princípio espiritual do mundo, uma concreção singular inserida no todo e na unidade de todos os entes. Como admite Scheler (2009, p. 136), este amor não é concebido nem sustentado sem uma base teísta. Dizendo em termos cristãos, a relação pessoal com Deus não exclui o amor ao próximo e todos os demais seres finitos; pelo contrário, exige uma amar tudo e todos em Deus e $a$ partir de Deus. Para o contexto da discussão, entretanto, deve-se ressaltar o aspecto ontológico-vivencial, a unificação afetiva vital-cósmica como polo oposto e basal desta comunhão pessoal com Deus, pois é necessário um eros enquanto tendência fundamental e inerente à vida humana mesma, para que esta se mostre como o misterioso entrar em contato com a vida universal, como um "desejo" de se unir com o todo. Pois em sua ausência ou obscurecimento, tal como no mundo moderno, não se sentiriam os homens vitalmente vinculados ao cosmos por inteiro, incluindo a natureza orgânica, à terra como sua "grande e eterna mãe". A incapacidade desta unificação afetiva cósmica do homem moderna se faz ver na destruição da natureza com fins capitalistas, na dominação do mundo orgânico por meio das ciências, bem como na restrição do "objeto" amado ao homem, porém, enquanto sujeito abstrato de razão, que funda o moderno humanitarismo (amor a todos os homens, não à pessoa na concretude de sua singularidade e, por isto, em verdade e rigorosamente, a nenhum ser humano). Por mais que o amor seja um ato espiritual, portanto, livre de toda a determinação psicofísica da estrutura humana, também em sua forma mais elevada, necessita de íntima cooperação deste "amor" de base, mais rigorosamente dizendo, desta função elementar do simpatizar, que é a unificação afetiva. pessoa com seus valores particularíssimos, portanto, não seria possível dirigir-se intencionalmente para o sentimento alheio (Mitgefühl). De outro lado, porém, não se saberia quem é o outro justamente na singularidade de sua condição, com suas experiências vividas (não o mero saber de seu ser-real), caso faltasse ao ser humano o poder de tender ao próximo que o compreende como outro eu na individualidade de suas experiências vividas (certamente, desde que a pessoa conhecida já se tenha aberto espontaneamente a este conhecimento), por exemplo, colhendo intencionalmente as suas dores e alegrias e, assim, poder participar de sua realidade - tal como se dá ao sentir os pesares e os gozos de um personagem romanesco. Porém, este tender simpatizatizante é, geralmente, indiferente aos valores personalizados e, assim, necessita do amor que o impele a uma genuína compreensão das vivências alheias; caso contrário, sem o desvelamento e a manifestação do outro como a presença de um centro espiritual individual no homem, isto é, exclusivamente dentro dos limites do sentir-com, o outro poderia ser tão facilmente restringido à um eu genérico e, concomitantemente, o amor ao ato ou vivência psíquica que se dirige meramente à humanidade como um gênero ou abstrato ser de razão. Então, ontologicamente, o ato amoroso é primaz, pois o ser-pessoa no homem, em seus atos noéticos, toma o eu como realidade psicovital apenas como a subestrutura e instrumento em base da qual é possível edificar um conhecimento do outro, no sentido da compreensão espiritual, a partir da evidência do seu valor pessoal. Porém, na ordem do dar-se desta compreensão, do desenvolvimento da experiência em que uma pessoa se dá ao conhecimento da outra, a ordem é inversa e o tender intencional e compreensivo do sentir-comoutro toma o primeiro lugar:

“(...) a pessoa (seus puros atos noéticos e o sentido destes atos) somente pode chegar à doação (datidate, Gegebenheit) de si a um outro, quando foi, por meio do sentir-com (Mitgefühl), prontamente consumada a atitude de tomada de realidade do outro como [eu] vital (Vitalisch), igual ao [eu] vital próprio, respectivamente, de seu substrato; e, edificado sobre este, o espontâneo amor ao homem avança penetrando sempre mais estratos de profundidade, até o ponto em o ser-pessoa no homem começa” (SCHELER, 2009, p. 109, tradução minha).

Este tender simpatizante, por sua vez, estaria impossibilitado desde a raiz se, por acaso, faltassem ao homem as forças de, a clara distância, sentir o que o outro sente, sem porém confundir o sentimento do próximo como sendo seu, mas "refazendo-o" sucessivamente em um 
ato compreensivo (Nachfühlung). Mas como seria tal distância possível se não fosse vivida, de antemão, uma comunhão com os outros e se não estivessem estabelecidas previamente entre os homens específicas comunidades de vida? Ora, antes, é mister a experiência primeva de sentirse um com o outro (Einsfühlung) no conjunto de sujeitos, na maioria das vezes, com aquele grupo em que os membros comungam os mesmos valores e compartilha da mesma hierarquia axiológica, como a família ou o grupo social mais imediato, entretanto, que se pode expandir à consciência pré-teórica de povo, de cultura e até de ligação aos antepassados. Diferentemente das experiencias anteriores, intencionais por essência, esta identificação e unificação afetiva com certo "gênero" de sujeitos é um acontecimento subconsciente, resultado de ação automática (não livre, em radical oposição aos atos espirituais) e restrita ao âmbito da consciência psicovital. Assim, as formas "superiores" do simpatizar estão fundadas no âmbito do viver o mesmo ao longo do experienciar-se, do viver-se nas relações consigo, com os outros, com a natureza. Na medida que o simpatizar ultrapassa esta dimensão originária do viver, na pretensão de uma pureza intelectual ou meramente intrapsíquica-subjetiva, decaise naturalmente na representação ou ficção das qualidades das situações com a qual se simpatiza, algo inteiramente possível por meio do nachfühlen. Porém, com uma imagem ou construto fictício ou ideia não se une afetivamente e todo genuíno sentircom estaria, de princípio, impedido.

Em segundo lugar, a alegada redução possui suas origens na conduta intelectualista em que o fenômeno da simpatia foi interpretado. Esta foi responsável por converter, dizendo grosso modo, a intencionalidade do sentir-com ou do sentir dirigido aos atos afetivos do outro na reprodução subjetiva das vivências alheias. Acerca desta reversão, muito já foi dito anteriormente e, mediante a distinção entre unificação e contágio afeito, continuará a ser esclarecida. Por fim, em razão da valorização utilitária e prática do simpatizar, que decorre na superestimação dos modos da congratulação e do compadecimento, porém, com predominante tendência de valorizar em maior grau o segundo em relação ao primeiro. Por certo, uma restrição ontológica e valorativa que possui as suas fontes na concepção intelectualista e burguesa do amor, vigente desde que ressentimento moderno transformou o amar em fazer o bem; promover o bemestar humano na maior extensão possível; no querer o bem e auxiliar, filantropicamente, qualquer um que seja, somente pelo fato de nele residir o abstrato ser humano universal, portador de direitos (Scheler, 2007, pp. 78-79, 97). E destinando o cristianismo para outras sendas, tornou-se sentimento de pena e (falsa) piedade para como que é pervertido, menor, privados, miserável ou doente, vítima de catástrofes naturais, sociais e econômicas. Então, desde que o amor se confunde com a patológica avidez por compaixão e simultaneamente, como alerta Kierkegaard (2014, p. 130), o compadecer é esteticamente submetido ao fenômeno do infortúnio, restringindo-o à "mais miserável de todas as virtuosidades e habilidades sociais". Assim pervertida, "a compaixão está tão longe de beneficiar o padecente, que antes nela só conservamos nosso próprio egoísmo".

Individualmente e em conjunto, todos estes fatores demostram quão longe a simpatia está do mero sentir a mesma dor do outro, do alegrar-se com a mesma alegria. Isto significa: encontra-se fenomenologicamente separada e radicalmente distante do contágio afetivo (Gefühlsansteckung), fenômeno tão ingenuamente prezado na moralidade e concepções cotidianas. Para evitar a corrente e errônea equiparação dos autênticos atos de compreensão da vida alheia com estes fenômenos, Scheler (2009, pp. 25-26) acentua algo que lhes é essencial: por serem desprovidos da intencionalidade própria ao sentir ou perceber afetivo (Fühlen) das vivências alheias, são os contágios verdadeiros estados emotivos (Gefühlszustände) ${ }^{13}$ que, mediante processos automáticos e inconscientes, tornamse um sentimento coletivo. Portanto, não são imediatamente referidos a um sentir originário e personalizado, mas a processos de mediação de uma sensação que, somente posteriormente, por meio de reflexão ou memória, são remetidos para objetos e situações. A associação com a possível causa do sentimento é mecânica, casual e, tantas vezes, hipotética, em razão do sujeito infectado não poder referir-se, com evidência, o que em certa circunstância o fez alegre ou triste. Nestes estados emotivos, cai-se sem saber a causa. Na maior parte das vezes, contenta-se em indicar: "uma energia que vibra no ar!”. Seu modo de infectar, por este caráter essencialmente mecânico, dá-se, na maioria das vezes, por intermédio dos fenômenos expressivos e da repetição imitativa da mesma expressão, por exemplo, mediante a excitação eufórica da massa ou de dado ambiente festivo. É deste modo que a circunstância coletiva toma o ânimo dos sujeitos envolvidos no processo de contágio, de um modo tal que se entregam ao sentimento que, por sua vez, surge independente das metas conscientes e se propaga para além propósito deliberado dos sujeitos infectados. Difícil, então, determinar sua proveniência; pelo contrário, contagia-se e se é contagiado num processo recíproco de infecção, gerando como que um acúmulo de emoções coletivas, como no fato da formação da opinião pública. Nestes estados, inclusive, pode faltar por inteiro a presença das vivências internas de um sujeito determinado e, consequentemente, também a intenção de participar da dor e da alegria do próximo. Pode-se, por exemplo,

13 Para delimitação dos estados emotivos, em contraposição ao sentir originário e intencional, Fühlen von, cfr. Scheler, 2000a, pp. 262-263. 
ser contagiado pela Stimmung, a tonalidade afetiva que habita a paisagem, o clima, o território, um povo ou grupamento de pessoas. É justamente nisto que a difusão da congratulação ou do compadecimento não se mostram como formas autênticas de simpatia. Se falta o outro com seu concreto mundo interior, alegrase com a própria alegria, mesmo estando rodeado de pessoas alegres; entristece-se com o próprio padecer, embora chorando com os outros. É apenas quando se congratula com alegria do próximo como sendo a felicidade alheia ou se compadece com a dor que é um sofrimento que não nos pertence, então, se desfaz o contágio. Sem a experiência do próximo como próximo (dele mesmo com seus pesares e alegrias) e da distância que se abre na proximidade, então, trata-se não de simpatia, mas sim de egoísmo, de autoerotismo; então, a propalada postura ética do sofrer-com seria uma masoquista multiplicação de misérias.

Entrementes, é justo ressaltar uma ambiguidade: a unificação afetiva é também uma forma de contágio, não obstante seu caráter originário. Ela o é tão somente na medida em que é o fenômeno responsável pela identificação daqueles que se unificam em uma primitiva "simpatia". Trata-se, pois, de um acontecimento identificante, de eventos em que os egos envolvidos se fusionam e, por força de sua causalidade ser estritamente vital, não está isenta de decair em completa confusão egoica, na absorção de um dos egos nos fluxos anímicos do outro, aniquilando a distância intencional entre eles. Quando a (con)fusão acontece, isto oscila em dois polos: o idiopático (o eu alheio é totalmente absorvido no ego simpatizante) ou heteropático (o eu simpatizante se alheia e se perde no ego com que ele simpatiza). Nem toda fusão, porém, necessita ser confusão. Neste sentido, exemplos genuínos deste fenômeno são a afetividade dos povos primitivos, o totemismo, os mistérios religiosos da Antiguidade, a relação entre hipnotizador com o hipnotizado, o fenômeno da fusão mútua propiciada pelo ato sexual, entre outros analisados por Scheler (2009). Preservando seu dinamismo originário, elas permitem um encontro afetivo-cognoscitivo com aquilo ou aquele com que se unifica. Nos intercâmbios humanos, são, de fato, de grande importância para o conhecimento das vivências alheias, precisamente em razão da principal caraterística que diferencia a unificação afetiva de todos os demais fenômenos e funções simpatizantes. Eis que elas acontecem, dentro da estrutura da constituição psicofísica e espiritual do homem, essencialmente unitária, no "entre" estabelecido entre os atos noético-espirituais responsáveis pela personalização dos conteúdos da vida interior e a dimensão corporal com suas sensações orgânicas e sentimentos sensíveis, portanto, no "reino intermédio" da consciência vital. É esta, pois, a região de atuação das funções específicas da vida psíquica:
É a região e atmosfera anímica do impulso de vida e de morte, das paixões, dos afetos, das necessidades pulsionais e impulsos (e suas três espécies essenciais: de fome e sede enquanto impulso de nutrição; do impulso vital erótico com todas as suas formas subordinadas; do impulso de poder, domínio e crescimento de poder, do fazer-se respeitar), os quais podem conduzir para unificação e genuína identificação nas manifestações de consciência a ela pertencentes (Scheler, 2009, p. 46; tradução minha).

Mediante todas as profundas conexões estabelecidas nesta região, a unificação afetiva conduz para a simpatia, à medida em que surgem por si mesmas relações pré-conscientes que dão origem à unidade psíquica vital. Embora não constituam uma participação espiritual no viver do próximo e, pelo contrário, exigem certo movimento de "despersonalização" do homem ao não se atentar, por momentos, de sua individualidade espiritual, descendo da esfera noética, estas conexões não deixam de ser supraempíricas. Pois neste humilde despojamento de sua dignidade espiritual, o homem não se reduz à bruta animalidade, àquele animal de rebanho, para usar uma expressão cara à Nietzsche, o que geralmente acontece quando se comporta como um gregário de massas; ao contrário, elevase nobremente sobre suas pulsões (Scheler, 2009, p. 46). Assim, as autênticas identificações afetivas nada apresentam de mecânico como as sensações corporais, nem de imitativo como o mero contágio de emoções. Ao invés disto, promovendo a descida do ego das alturas da pura razão e o abandono dos ditames da razão, elas incitam para uma íntima adesão ao outro, doando a base fenomenal para o conhecimento do fluxo vivencial de seu mundo psíquico, desde seu conteúdo e dinamismo interno e, deste modo, não como um expectador externo com o uso de teorias objetivantes.

Todavia, a simpatia, enquanto fenômeno sui generis, apresenta algo mais que a diferencia daquelas fusões, mesmo que autênticas. Primeiramente, ela necessita ser a experiência de dirigir-se intencional para os atos pessoais do outro. Como dito, elas são a compreensão de um sentir-com que sabe da distância que dilacera e distingue o meu eu do eu do outro. Onde não há alteridade e originária compreensão dela, também não há simpatia. Com efeito, simpatizar não é só viver o mesmo que outrem, mas a decisão livre, própria de um ser espiritual, de tomar parte na abertura do ser pessoal alheio, participar de seus atos intencionais no modo único com que os atos permitem tal participação: correalizando ou realizando coativamente (previamente, durante ou sucessivamente) o mesmo sentir (Scheler, 2000a, p. 386). Para tanto, não basta unicamente o originário sentir-com, ou seja, aquele 
estar no mesmo movimento afetivo que se dirige intencionalmente para determinado objeto, pessoa ou circunstância que, com seus valores, faz alegrar ou padecer. Embora este feito heroico, por assim dizer, seja radicalmente disposto para ir além do egocêntrico sentir o mesmo que o outro na mera repetição de suas penas e gozos, ao permitir que tanto o penar e o que causa a pena (como também o alegrar e aquilo que suscita a alegria) sejam uma única e mesma coisa, necessária é ainda uma "virada transcendental" para a vivência do outro, no sentido de (a)ter ao álter, de fato, como próximo na distância. O simpatizar propriamente dito, portanto, não surge automaticamente ou por mera reprodução das vivências alheias, mas sim de um giro intencional permitido por atos de compreensão que percebem mediante funções exclusivamente afetivas a dor e a alegria do outro (Scheler, 2009, pp. 24-25). Somente no sentido de serem compreendidas e vividas como fenômenos pertencentes somente ao próximo, a simpatia, então, possui algo de reativo, específico de um ato não objetivante, mas receptivo por intenção, portanto, apto para apreender o valor das vivências alheias. Com isto, simpatizar é a intrépida disposição de refazê-las afetivamente sem tomá-las como suas. Certamente, é isto revivê-las, remetê-las para si em "gesto" de acolhida. Contudo, fundado naquele giro intencional realizado pelo ato de dirigir-se para o sentimento alheio (Mitgefühlen), este refazer não se degrada no sentir o mesmo o que outro, normalmente, desencadeado pelo automatismo do contágio afetivo justamente quando falta tal base.

Em segundo lugar, a simpatia propriamente dita vai muito além união afetiva. Por se instalar no intermédio da estrutura orgânica e do centro livre dos atos espirituais com os seus correlatos, a união afetiva não penetra nesta última camada que é a do ser-pessoal. Ora, a plena consciência da alteridade dos outros também não pode surgir por meio do conhecimento compreensivo sem um apreensão do conteúdo individual, por mais inefável que seja, que constitui a concreta singularidade da pessoa; não se efetiva mediante o conhecimento que dá conta das vivências particulares, porém, limitado no âmbito psico-vital. Caso contrário, como comumente acontece em algumas teorias psicológicas, há sempre a tendência de submeter a particularidade das vivências psíquicas de outrem às leis dos mecanismos de associação; a generalizações de suas qualidades e à conformação a um sistema de tipificação dos humanos em relação à sua estrutura psíquica; à interpretação segundo a compreensão de seu ser social de acordo com a imagem e as relações sociais do grupo ao qual pertence (Scheler, 2009, p. 131), isto é, transformar a particularidade das vivências psíquicas em fenômenos de consciência e de conhecimento dos fatos anímicos que tem sua origem em (pre)determinados julgamentos e papéis sociais. Consequentemente, grosso modo, para que a simpatia vigore como fenômeno humano, demasiadamente humano e, deste modo, seja fonte pura e límpida do conhecimento da unidade espiritual do outro enquanto seu ser-assim mais originário ou do modo singularíssimo de ser si mesmo, é preciso que na unificação afetiva se imiscuam as forças do espírito. Mister se faz que na simpatia se empreguem todas as potências do ânimo ou do coração, nãos só as vitais-psíquicas, e que, de grau em grau, desenvolvam-se até alcançar as esferas mais nobres.

À guisa de conclusão, porém, é preciso lembrar, melhor, aludir a noção fundamental do pensamento fenomenológico de Scheler: se admitese que o homem, nas profundezas de sua essência ou de sua condição espiritual não é ego cogito nem ego volens, mas sim um ens amans (Scheler, 2000d, p. 356), somente quando o intercâmbio individual é guiado pelo amor espiritual à pessoa que é possível penetrar no mistério da singularidade própria e alheia. O originário conhecimento de si e do outro, na fenomenologia de Scheler, apresenta esta marca incontornável do ato de amor que, por ser o único ato que antecipa o conhecimento ao reconhecer previamente o bem e valores do amado, é capaz de guiar as relações da pessoa consigo mesma e com as demais. Deste modo, quando se trata de saber a verdade do álter, é preciso sim admitir uma resposta afirmativa à pergunta se o simpatizar é sentir as dores e alegrias do outro, porém, quando este ato de sentir-com se mostra no sentido de um "amoroso giro transcendental” para o mundo afetivo alheio. E do ponto de vista do mais eticamente valoroso, simpatizar-se é mais que o compadecimento. É o ponto de partida para um grande amor que supera a compaixão, que eleva-se para além do sofrer (intencionalmente) com o outro, para criar o que ama ao deixar ser e convocar o amado a vir a ser plenamente o bem que é. E nisto, acima de tudo o mais, congratular-se.

\section{Referências}

Dufrenne, M. (1972). Estética e filosofia. São Paulo: Perspectiva.

Freud, S. (2011). Mal estar na civilização. São Paulo: Peguin Classics/Companhia das Letras.

Heidegger, M. (2006). Was ist das - die Philosophie?. In Martin Heidegger. Identität und Differenz (pp. 3-26). GA 11. Frankfurt: Vittorio Klostermann.

Husserl, E. (1996). Die Krisis der europäischen Wissenchaften und die tranzendentale Phänomenologie. Hamburger: Felix Meiner.

Jung, C. G. (1977). Chegando ao inconsciente. In C. G.Jung. O homem e seus símbolos (pp.18-103). Rio de Janeiro: Nova Fronteira. 
Kierkegaard, S.A. (2014). O conceito de angústia. Petrópolis: Vozes.

Merleau-Ponty, M. (2004). O olho e o espírito. São Paulo: Cosa \& Naif.

Nietzsche, F. (2011). Assim falou Zaratustra. São Paulo: Companhia das Letras.

Pascal, B. (2005). Pensamentos. São Paulo: Martins Fontes.

Scheler, M. (2000a). Der Formalismus in der Ethik und die materiale Wertethik. GW 2. Bonn: Bouvier.

Scheler, M. (2000b). Ordo Amoris. In Max Scheler. Schriften aus dem Nachlaß. Zur Ethik und Erkenntnislehre (pp. 345-76). GW 10, Band I. Bonn: Bouvier [Max Scheler, 2012, Ordo amoris. Tradução de Artur Morão. Disponível em http://www.lusosofia.net/textos/20120726-scheler_ordo_amoris.pdf]

Scheler, M. (2003). Para a ideia de homem. In Max Scheler. A posição do homem no cosmos (pp. 91-123). Rio de Janeiro: Forense Universitária.

Scheler, M. (2007a). Das Ressentiment im Aufbau der Moralen. In Max Scheler. Vom Umsturz der Werte (pp. 33-147). GW 3. Bonn: Bouvier.

Scheler, M. (2007b). Zur Idee des Menschen. In Max Scheler, M. Vom Umsturz der Werte (p. 171195). GW 3. Bonn: Bouvier;

Scheler, M. (2008a). Vom Sinn des Leides. In Max Scheler. Schriften zur Soziologie und Weltanschauungslehre (pp. 36-72). GW 6. Bonn: Bouvier.
Scheler, M. (2008b). Vom Verrat der Freude. In Max Scheler. Schriften zur Soziologie und Weltanschauungslehre (pp. 73-76). GW 6. Bonn: Bouvier.

Scheler, M. (2008c). Die Stellung des Menchen in Kosmos. In Max Scheler. Späte Schriften (pp. 7-71). GW 9. Bonn: Bouvier.

Scheler, M. (2009). Wesen und Formen der Sympathie. GW 7. Bonn: Bouvier.

Teixeira, C. M (org.). (2004). Fontes franciscanas e clariana. Petrópolis: Vozes.

Vattimo, G. (2017). O sujeito e a máscara. Nietzsche e o problema da libertação. Petrópolis: Vozes.

Daniel Rodrigues Ramos (ORCID 0000-0001-60594400). Professor Adjunto do Curso de Filosofia da Universidade Federal do Recôncavo da Bahia (UFRB). Atua no Centro de Formação de Professores (CFP), Amargosa (BA). Email: dr.ramos@outlook.com.br

Recebido em 17.02.2020

Primeira Decisão Editorial em 16.04.2020

Aceito em 06.05.2020 